Volume 2 Nomor 1 Edisi Juni 2013

ISSN 2354-7200
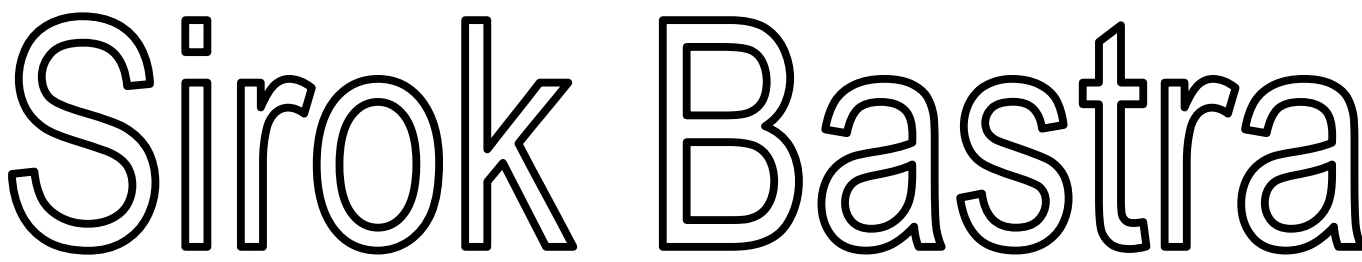

JURNAL ILMIAH KEBAHASAAN DAN KESASTRAAN

\begin{tabular}{|c|c|l|c|c|c|}
\hline $\begin{array}{c}\text { Sirok Bastra } \\
\text { Jurnal Kebahasaan dan } \\
\text { Kesastraan }\end{array}$ & Volume 2 & Nomor 1 & $\begin{array}{c}\text { Hlm. } \\
1-120\end{array}$ & $\begin{array}{c}\text { Pangkalpinang, } \\
\text { Juni 2013 }\end{array}$ & $\begin{array}{c}\text { ISSN } \\
2354-7200\end{array}$ \\
\hline
\end{tabular}

KANTOR BAHASA PROUINSI BANGKA BELITUNG 


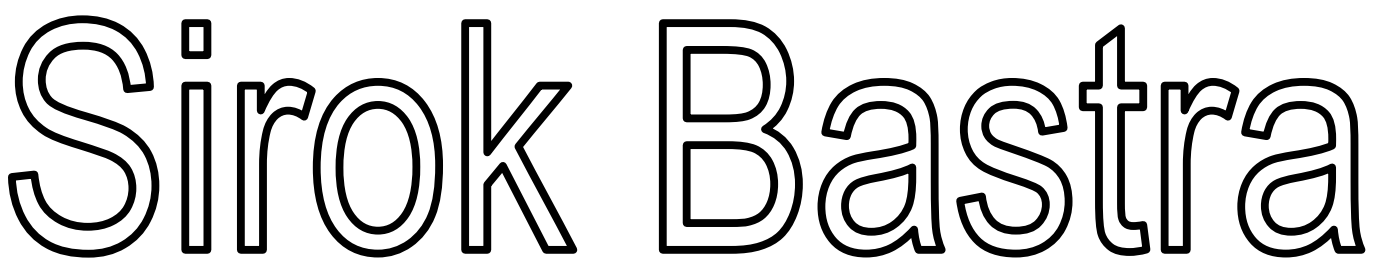

\section{JURNAL ILMIAH KEBAHASAAN DAN KESASTRAAN}

Jurnal ini merupakan wadah informasi mengenai kebahasan, kesastraan, dan pengajarannya yang memuat hasil penelitian, studi kepustakaan, dan tulisan ilmiah bidang kebahasan dan kesastraan serta pengajarannya. Sirok Bastra terbit dua kali setahun, yakni Juni dan Desember, serta terbit sejak Juni 2013.

\section{Penanggung Jawab}

Kepala Kantor Bahasa Provinsi Bangka Belitung Drs. Umar Solikhan, M.Hum.

\section{Mitra Bestari}

Prof. Dr. Agus Nuryatin, M.Hum. (Bidang Sastra dan Pengajarannya)

Prof. Amrin Saragih, Ph.D., M.A. (Bidang Bahasa dan Pengajarannya)

Dr. Felicia Nuradi Utorodewo, M.Hum. (Bidang Bahasa dan Pengajarannya)

Dr. Pujiharto, M.Hum. (Bidang Sastra dan Pengajarannya)

\section{Pemimpin Redaksi}

Rahmat Muhidin, S.S.

\section{Penyunting}

Prima Hariyanto, S.Hum.

\section{Perancang Sampul}

Feri Pristiawan, S.S.

\section{Kesekretariatan}

Khaliffitriansyah, S.Pd.

Dea Letriana Cesaria, S.Hum.

Lia Aprilina, S.Pd.

Andrian Priyatno, A.Md.

Elzam

\section{Alamat Redaksi dan Penerbit}

Kantor Bahasa Provinsi Bangka Belitung

Ruko Permata 7, Jalan Solihin G.P. Km 4, Kota Pangkalpinang, Prov. Kepulauan Bangka Belitung

Telp./Faks.: 0717-438455, Pos-el: sirokbastra@gmail.com

Pemuatan suatu tulisan dalam jurnal ini tidak berarti redaksi menyetujui isi tulisan tersebut. Isi tulisan menjadi tanggung jawab penulis. Tulisan telah ditinjau dan diulas oleh mitra bestari. Setiap karangan dalam jurnal ini dapat diperbanyak setelah mendapat izin tertulis dari penulis, redaksi, dan penerbit. 


\section{PENGANTAR}

Puji syukur ke hadirat Pemilik dan Pencipta semesta ini yang memiliki kuasa atas diri-Nya sendiri. Dialah Tuhan Yang Maha Esa yang telah memberikan rahmat dan hidayah-Nya sehingga Volume 2 Nomor 1 Jurnal Sirok Bastra Tahun 2014 dapat terbit tepat pada waktunya.

Pada edisi ini, dimuat sepuluh tulisan, yakni enam tulisan kesastraan dan empat tulisan kebahasaan. Dalam kajiannya, Anita Rima Dewi melihat kedudukan perempuan Jawa dalam keluarga — tergambar dalam novel Hati Sinden karya Dwi Rahyuningsih — dilihat dari perspektif gender. Berdasarkan penelitian, ditemukan bahwa diskriminasi gender seperti marginalisasi, stereotipe, dan subordinasi melahirkan berbagai kekerasan, yakni ekonomi, fisik, psikis, dan seksual.

Dalam kajiannya, Sarman membahas mitos buluh perindu dalam cerita rakyat Bangka. Mitos Bukit Tambun Tulang memuat struktur geografis yang menunjukkan adanya pola perjalanan hidup tokoh dalam mempertahankan hidup; struktur tekno-ekonomi yang menunjukkan adanya sistem mata pencaharian orang Bangka, antara lain berburu dan berkebun; struktur sosiologis yang menunjukan adanya hubungan sosial antara sesama manusia; dan struktur kosmologis yang menunjukkan adanya keterkaitan antara dunia nyata dan dunia gaib.

Dalam penelitiannya, Iis Afriatiningsih membahas sosok perempuan dalam karya sastra Indonesia yang diwakili oleh Nyai Ontosoroh, Pariyem, Clara yang menghadapi banyak tantangan dalam hidupnya. Hasil analisis menunjukkan bahwa sosok perempuan memiliki sikap, seperti memperjuangkan hidupnya (tergambar dalam tokoh Nyai Ontosoroh), pasrah dengan nasibnya (tergambar dalam tokoh Pariyem), dan nasibnya ada di tangan rakyat kecil (tergambar dalam tokoh Clara). Perjuangan perempuan tersebut berkaitan dengan kritik formalisme, strukturalisme, posstrukturalisme, dan posmoderenisme.

Dalam kajiannya, Asep Supriadi mengaplikasikan teori takmilah yang digagas oleh seorang pakar sastra Melayu bernama Shafie Abu Bakar pada puisi "Idul Fitri" karya Sutardji Calzoum Bachri. Hasil kajian menunjukkan bahwa puisi tersebut menggambarkan nilai-nilai keislaman dengan dimensi sufistik. Puisi itu menggambarkan perenungan eksistensi diri pada Tuhan.

Dalam kajiannya, Ch. Haris Maulana membahas tokoh dan penokohan serta nilai moral dan kekhasan yang ada dalam serial Harry Potter, khususnya seri pertama, Harry Potter dan Batu Bertuah. Nilai moral dan kekhasan yang tersirat dalam serial ini adalah sihir dapat dipelajari dan bukan faktor keturunan, kesetiakawanan, kedisipilinan, kepedulian, dan keingintahuan.

Dalam penelitiannya, Dwi Oktarina menggali aspek hibriditas dan ambivalensi yang terjadi pada tokoh Mata Hari dalam novel Namaku Mata Hari karya Remy Silado. Mata Hari, seorang agen spionase keturunan Belanda-Jawa bekerja pada banyak negara pada saat perang dunia berkecamuk. Selain itu, permainan politik tubuh Mata Hari juga menjadi sebuah hal yang menarik untuk diteliti lebih jauh. Berdasarkan penelitian, didapatkan hasil bahwa ruang-ruang pertemuan antara dua kebudayaan sama sekali tidak bisa dielakkan. Mata Hari sebagai Indo berdarah campuran Belanda-Indonesia tidak dapat melepaskan dirinya dari dua kebudayaan yang melingkupinya, Belanda maupun Indonesia.

Dalam kajiannya, Maria Christa Istiana Kamagi membahas struktur kalimat dan keterbacaan pada buku teks pelajaran bahasa Indonesia. Berdasarkan penelitian, ditemukan kalimat tunggal perluasan subjek, predikat, objek, dan pelengkap, kalimat tunggal perluasan keterangan, kalimat majemuk setara, kalimat majemuk bertingkat, kalimat majemuk bersusun, dan kalimat taklengkap. Selain menjelaskan struktur kalimat yang ada, penelitian ini juga mencoba menganalisis keterbacaan dilihat dari jumlah kata yang digunakan dalam kalimat tersebut. Hasil yang didapat adalah terdapat beberapa kalimat yang masih masuk kategori kalimat sulit dan sangat sulit dipahami.

Dalam kajiannya, Achril Zalmansyah membahas hasil Uji Kemahiran Berbahasa Indonesia (UKBI) guru dan siswa SMP di Kabupaten Lampung Utara. Data yang diperoleh menunjukkan bahwa sebagian besar peserta memperoleh nilai antara 300-400 yang berarti cukup baik. Dengan demikian, dapat dikatakan bahwa UKBI 
merupakan alat uji yang dapat digunakan untuk mengukur penguasaan bahasa Indonesia seorang guru serta penggunaan bahasa Indonesia yang baik dan benar oleh siswa.

Dalam kajiannya, Prima Hariyanto membahas kata berinfiks -er- dalam bahasa Indonesia. Korpus data penelitian ini adalah Kamus Besar Bahasa Indonesia Edisi Ketiga. Berdasarkan penelitian yang dilakukan, ditemukan 62 kata berinfiks -er- yang terdiri dari 14 jenis kelompok makna. Selain memaparkan kata berinfiks yang ada, penelitian ini juga mencoba memaparkan metode pendefinisian lema kata berinfiks yang -er-bermakna 'sama dengan bentuk dasarnya' dalam Kamus Besar Bahasa Indonesia.

Dalam penelitiannya, Hotnida Novita Sary mengkaji perbedaan bentuk verba yang terdapat dalam bahasa Melayu Tinggi dan bahasa Melayu Rendah yang terdapat dalam Injil Matius terjemahan Klinkert. Peneliti mengunduh data dari laman sabda.org. Kedua versi Injil Matius ini kemudian dibandingkan dan dicatat satu ayat dengan ayat yang sama. Hasil pencatatan inilah yang dianalisis. Hasil yang didapatkan dari penelitian ini adalah ragam bahasa Melayu Tinggi cenderung menggunakan bentuk berimbuhan, sedangkan bahasa Melayu Rendah cenderung menggunakan bentuk dasar.

Kami mengucapkan terima kasih kepada para penulis yang telah bersedia menerbitkan karya mereka pada edisi ini. Para penulis merupakan peneliti, pakar, dosen, siswa, dan mahasiswa dari berbagai sekolah, perguruan tinggi, dan instansi. Terima kasih juga kami sampaikan kepada para mitra bestari kami yang telah memberi ulasan terhadap tulisan-tulisan yang masuk ke redaksi.

Demi memenuhi keberagaman isi dan penulis, Sirok Bastra membuka kesempatan bagi para peneliti dan penulis menyampaikan hasil penelitian dan pemikiran mutakhir dalam bidang kebahasaan, kesastraan, dan pengajarannya.

Pangkalpinang, Juni 2014

Tim Redaksi 


\section{UCAPAN TERIMA KASIH UNTUK MITRA BESTARI}

Redaksi Sirok Bastra mengucapkan terima kasih kepada para mitra bestari yang telah meninjau, menimbang, dan mengulas makalah-makalah yang diterbitkan dalam Sirok Bastra Volume 2 Nomor 1, edisi Juni 2014, yakni

Prof. Dr. Agus Nuryatin, M.Hum.

Bidang Sastra dan Pengajarannya

Universitas Negeri Semarang

Semarang, Jawa Tengah

Prof. Amrin Saragih, Ph.D., M.A.

Bidang Bahasa dan Pengajarannya

Universitas Negeri Medan

Medan, Sumatra Utara

Dr. Felicia Nuradi Utorodewo, M.Hum.

Bidang Bahasa dan Pengajarannya

Universitas Indonesia

Depok, Jawa Barat

\section{Dr. Pujiharto, M.Hum.}

Bidang Sastra dan Pengajarannya

Universitas Gadjah Mada

Yogyakarta, Daerah Istimewa Yogyakarta 


\section{DAFTAR ISI}

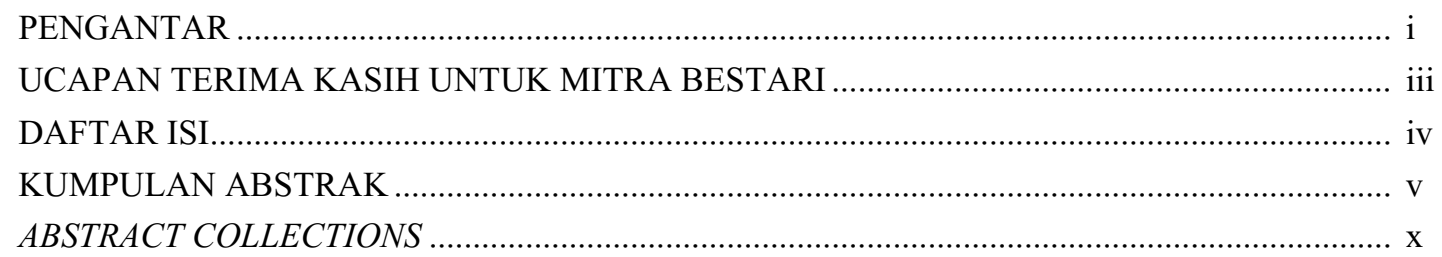

KEDUDUKAN PEREMPUAN JAWA DALAM NOVEL HATI SINDEN KARYA DWI RAHYUNINGSIH DILIHAT DARI PERSPEKTIF GENDER

(The Position of Javanese Women Based on Gender Perspective in Hati Sinden, a Novel by Dwi Rahyuningsih)

Anita Rima Dewi $1-15$

MITOS DALAM CERITA “BUKIT TAMBUN TULANG”

(Myth in "Bukit Tambun Tulang" Story)

Sarman. $17-24$

SOSOK PEREMPUAN DARI ZAMAN KE ZAMAN DALAM KARYA SASTRA INDONESIA: STUDI KASUS TOKOH NYAI ONTOSOROH, PARIYEM, DAN CLARA (Figure of Women from Time to Time in Indonesian Literary Works: A Case Study of Nyai Ontosoroh, Pariyem, and Clara)

Iis Afriatiningsih $25-33$

MEMAHAMI PUISI "IDUL FITRI" DENGAN TEORI TAKMILAH

(Understanding the Poetry "Idul Fitri” by Using Theory of Takmilah)

Asep Supriadi $35-44$

NILAI DAN KEKHASAN SERIAL HARRY POTTER (KAJIAN HARRY POTTER 1: HARRY POTTER DAN BATU BERTUAH)

(Value and Uniqueness of Harry Potter Series [A Study of Harry Potter 1: Harry Potter and The Sorcerers Stone])

Ch. Haris Maulana $45-52$

HIBRIDITAS DAN POLITIK TUBUH DALAM NOVEL NAMAKU MATA HARI KARYA REMY SILADO: SEBUAH TINJAUAN POSKOLONIAL

(Hybridity and Body Politic in Namaku Mata Hari, A Novel Written by Remy Silado: A Postcolonial Study)

Dwi Oktarina $53-61$

STRUKTUR DAN KETERBACAAN KALIMAT PADA BUKU TEKS PELAJARAN BAHASA INDONESIA

(Sentence Structure and Readability in Indonesian Textbook)

Maria Christa Istiana Kamagi. $63-78$ 
UJI KEMAHIRAN BERBAHASA INDONESIA (UKBI) BAGI GURU DAN SISWA SEKOLAH MENENGAH PERTAMA SE-LAMPUNG UTARA

(Indonesian Proficiency Test [UKBI] for Teacher and Junior High School Students All Lampung Utara)

Achril Zalmansyah

KATA BERINFIKS -ER- DALAM BAHASA INDONESIA

(-er- Infixes Words in Indonesian)

Prima Hariyanto

$89-103$

PERBEDAAN BENTUK VERBA PADA BAHASA MELAYU TINGGI DAN BAHASA

MELAYU RENDAH: STUDI KASUS INJIL MATIUS TERJEMAHAN KLINKERT

(Verb Form of Differences in Language Malay Malay Language High and Low: Case Study of The Gospel of Matthew Klinkert Translations)

Hotnida Novita Sary .... $105-120$ 
Achril Zalmansyah: Uji Kemahiran Berbahasa Indonesia (UKBI) bagi Guru dan ...

\title{
UJI KEMAHIRAN BERBAHASA INDONESIA (UKBI) BAGI GURU DAN SISWA SEKOLAH MENENGAH PERTAMA SE-LAMPUNG UTARA
}

\section{Indonesian Proficiency Test (UKBI) for Teacher and Junior High School Students All Lampung Utara}

\author{
Achril Zalmansyah \\ Kantor Bahasa Provinsi Lampung \\ Jalan Beringin II No. 40, Kompleks Gubernuran Telukbetung, Bandarlampung \\ Telepon (0721) 486408, (0721) 480705, Faksimile (0721) 486407 \\ Pos-el: zzalmansa@gmail.com
}

(diterima 21 November 2013, disetujui 2 Mei 2014, revisi terakhir 10 Juni 2014)

\begin{abstract}
Abstrak
Uji Kemahiran Berbahasa Indonesia (UKBI) dirancang sedemikian rupa, tanpa mengenal jenis pekerjaan atau jabatan seseorang, sebagai alat uji yang sangat ideal, baik bagi penjaringan pekerja atau pegawai teladan, siswa/mahasiswa, guru maupun calon pegawai negeri sipil. Uji Kemahiran Berbahasa Indonesia bagi guru dan siswa sekolah menengah pertama merupakan salah satu hal baru bagi kalangan pendidikan di Kabupaten Lampung Utara sehingga perlu disosialisasikan dan diujikan. UKBI ini dilakukan untuk mengetahui penguasaan bahasa Indonesia para guru dan siswa sekolah menengah pertama di Kabupaten Lampung Utara. Data yang diperoleh menunjukkan bahwa sebagian besar peserta memperoleh nilai antara 300-400 yang berarti cukup baik. Dengan demikian, dapat dikatakan bahwa UKBI merupakan alat uji yang dapat digunakan untuk mengukur penguasaan bahasa Indonesia seorang guru serta penggunaan bahasa Indonesia yang baik dan benar oleh siswa.
\end{abstract}

Kata kunci: guru, siswa SMP, UKBI

\begin{abstract}
Indonesian Proficiency Test (UKBI) is designed in such a way, without referring to someone's job or position, as an ideal instrument for recruiting workers or qualified employees, students, teachers, and government employees. Indonesian Proficiency Test for teachers and students of junior high school in Lampung Utara is a new thing to the education community so that it should be sosialized and tested. The test is conducted to indicate the skills of teachers and junior high school students in mastering bahasa Indonesia. The data obtained shows that the majority of participants scores were between 300-400 which is above average. Thus, it is confimed that UKBI as a test tool that can be used to measure the ability of teachers in mastering bahasa Indonesia as well as the students' skills in the using of good and right bahasa Indonesia.
\end{abstract}

Key words: teacher, junior high school students, UKBI

\section{PENDAHULUAN}

\subsection{Latar Belakang}

Manusia merupakan makhluk yang perlu berinteraksi dengan manusia lainnya. Interaksi terasa semakin penting pada saat manusia membutuhkan pengakuan. Kegiatan ini membutuhkan alat, sarana, atau media, yaitu bahasa. Sejak saat itulah bahasa menjadi alat, sarana, atau media berkomunikasi. Di dalam kehidupannya bermasyarakat, sebenarnya manusia dapat juga menggunakan alat komunikasi lain selain bahasa. Namun, tampaknya bahasa merupakan alat komunikasi yang paling sempurna, dibandingkan dengan alat-alat komunikasi lain, termasuk alat komunikasi yang dipakai oleh hewan (Chaer, Abdul dan Leoni Agustina, 2010:11). Komunikasi yang dilakukan adalah komunikasi dalam bentuk formal dan tidak formal. Bahasa Indonesia formal lazim dikenal sebagai bahasa Indonesia standar atau baku, sedangkan dalam komunikasi tidak formal, kita mengenal bahasa yang tidak baku, yang kosakatanya umum atau lazim digunakan penuturnya di dalam pergaulan sehari-hari.

Dalam kaitannya dengan penggunaan bahasa baku atau standar dalam bahasa formal, dikenal istilah 
UKBI (Uji Kemahiran Berbahasa Indonesia). UKBI merupakan instrumen pengujian kemahiran seseorang berbahasa Indonesia. Dengan instrumen ini, setiap orang atau instansi dapat memperoleh informasi yang akurat tentang profil kemahiran berbahasa Indonesia mereka. UKBI telah menjadi sarana pengukuran yang berstandar nasional.

Sejarah Uji Kemahiran Berbahasa Indonesia (UKBI) dirintis melalui berbagai peristiwa kebahasaan yang diprakarsai Pusat Bahasa, Departemen Pendidikan Nasional. Gagasan awal terungkap dalam Kongres Bahasa Indonesia IV pada tahun 1983. Selanjutnya, dalam Kongres Bahasa Indonesia V pada tahun 1988 muncul pula gagasan tentang perlunya sarana tes bahasa Indonesia yang standar. Oleh karena itu, Pusat Bahasa mulai menyusun dan membakukan sebuah instrumen evaluasi bahasa Indonesia. Pada awal tahun 1990-an, instrumen evaluasi itu diwujudkan, kemudian dinamai dengan Uji Kemahiran Berbahasa Indonesia (UKBI). Sejak saat itu UKBI dikembangkan untuk menjadi tes standar yang dirancang guna mengevaluasi kemahiran seseorang dalam berbahasa Indonesia, baik tulis maupun lisan. Dengan UKBI seseorang dapat mengetahui mutu kemahirannya dalam berbahasa Indonesia tanpa mempertimbangkan lokasi dan jangka waktu ia telah belajar bahasa Indonesia. Sebagai tes bahasa untuk umum, UKBI terbuka bagi setiap penutur bahasa Indonesia, terutama yang berpendidikan, baik warga negara Indonesia maupun warga negara asing. Dengan UKBI, instansi pemerintah dan swasta dapat mengetahui mutu karyawan atau calon karyawannya dalam berbahasa Indonesia. Demikian pula, perguruan tinggi dapat memanfaatkan instrumen ini dalam seleksi penerimaan mahasiswa barunya. Melalui Surat Keputusan Mendiknas Nomor 152/U/2003 tanggal 28 Oktober 2003, Menteri Pendidikan Nasional telah mengukuhkan UKBI sebagai sarana untuk menentukan kemahiran berbahasa Indonesia di kalangan masyarakat.

Selanjutnya, Kantor Bahasa Provinsi Lampung telah menjadikan UKBI sebagai alat uji yang wajib dilakukan sebagai tes awal proses penyeleksian Duta Bahasa Provinsi Lampung yang sudah dilakukan sejak tahun 2007. Uji Kemahiran Berbahasa Indonesia juga dilakukan pada guru sekolah menengah pertama se-Kabupaten Pesawaran dan guru sekolah dasar seBandarlampung pada tahun 2010, serta digunakan untuk menjaring para calon duta bahasa di Provinsi Lampung. Selanjutnya, pada tahun anggaran 2013, pelatihan dan pengujian UKBI difokuskan pelaksanaannya pada guru bahasa Indonesia dan siswa sekolah menengah pertama pada lima kabupaten di Provinsi Lampung, yaitu: Kabupaten Lampung Tengah, Kabupaten Pesawaran, Kabupaten Lampung Utara, Kabupaten Lampung Selatan, dan Kabupaten Pesisir Barat.

\subsection{Rumusan Masalah}

Masalah utama yang ingin diungkapkan dalam penelitian ini adalah apakah Uji Kemahiran Berbahasa Indonesia (UKBI) diperlukan sebagai salah satu alat uji bagi guru dan siswa di Provinsi Lampung. Sebagai bahan pertimbangan, penulis hanya mengambil data hasil Uji Kemahiran Berbahasa Indonesia guru program studi bahasa Indonesia dan siswa sekolah menengah pertama yang dilakukan pada tanggal 2-4 September 2013 di Kabupaten Lampung Utara.

Adapun masalah utama tersebut dapat dibagi ke dalam beberapa submasalah sebagai berikut.

1) Bagaimana hasil Uji Kemahiran Berbahasa Indonesia bagi guru sekolah menengah pertama di Kabupaten Lampung Utara?

2) Bagaimana hasil Uji Kemahiran Berbahasa Indonesia bagi siswa sekolah menengah pertama di Kabupaten Lampung Utara?

3) Bagaimana hasil Uji Kemahiran berbahasa Indonesia (UKBI) guru dan siswa sekolah menengah pertama di Kabupaten Lampung Utara?

\subsection{Tujuan}

Penelitian ini dilakukan untuk mengetahui hasil Uji Kemahiran Berbahasa Indonesia (UKBI) guru bidang studi bahasa Indonesia dan siswa sekolah menengah pertama se-Kabupaten Lampung Utara.

\subsection{Manfaat}

Hasil penelitian ini, di samping dapat menjadi data Tim UKBI Pusat dan Balai/Kantor Bahasa, juga dapat menjadi masukan bagi pembinaan bahasa, khususnya pembinaan bahasa Indonesia bagi guru dan siswa di Provinsi Lampung. Penelitian ini juga diharapkan dapat menjadi bahan masukan bagi pengembangan 
Achril Zalmansyah: Uji Kemahiran Berbahasa Indonesia (UKBI) bagi Guru dan ...

alat uji UKBI sebagai uji dan tolok ukur seseorang di dalam penguasaannya terhadap bahasa Indonesia.

\subsection{Metode Penelitian dan Data}

\subsubsection{Metode Penelitian}

Metode penelitian ilmiah ini menggunakan analisis deskriptif kualitatif dan kuantitatif sederhana dengan menggunakan data primer yang diperoleh dari hasil Uji Kemahiran Berbahasa Indonesia bagi guru dan siswa sekolah menengah pertama se-Kabupaten Lampung Utara yang diselenggarakan oleh Kantor Bahasa Provinsi Lampung pada tahun 2013. Nilai akhir diperoleh dengan penghitungan komputer terhadap hasil peserta tes tersebut.

\subsubsection{Waktu dan Tempat}

Ranah penelitian ini adalah hasil Uji Kemahiran Berbahasa Indonesia yang dilakukan pada guru dan siswa sekolah menengah pertama se-Kabupaten Lampung Utara pada tanggal 2-4 September 2013 di SMP Bayangkari, Kotabumi, Lampung Utara.

\subsubsection{Teknik Pengumpulan Data}

Data dikumpulkan dari hasil Uji Kemahiran Berbahasa Indonesia yang dilakukan pada guru dan siswa sekolah menengah pertama se-Kabupaten Lampung Utara. Data yang diperoleh diolah berdasarkan analisis data kualitatif dan kuantitatif sederhana. Jumlah peserta uji dengan hasil tertentu kemudian dipersentasekan. Langkah selanjutnya, dilakukan analisis data kualitatif yang berisi uraian atau deskripsi untuk menjelaskan sifat (karakteristik) data yang diperoleh dan menghubungkannya dengan faktor-faktor yang melatarbelakanginya. Kemudian, pengolahan data dilanjutkan dengan penyimpulan hasil analisis data.

Untuk menentukan tingkat penguasaan bahasa Indonesia guru dan siswa sekolah menengah pertama ini digunakan batasan sebagai berikut.

1) Jika hasil UKBI antara 717-900, berarti penguasaan bahasa Indonesia istimewa (Sangat Unggul atau Istimewa).

2) Jika hasil UKBI antara 593-716, berarti penguasaan bahasa Indonesia sangat baik (Unggul).

3) Jika hasil UKBI antara 466-592, berarti penguasaan bahasa Indonesia baik (Madya).
4) Jika hasil UKBI antara 247-465, berarti penguasaan bahasa Indonesia cukup baik (Marginal atau Semenjana).

5) Jika hasil UKBI $<247$, berarti penguasaan bahasa Indonesia kurang (Terbatas).

Tes UKBI yang dilakukan pada guru dan siswa sekolah menengah pertama di Lampung Utara ini ditekankan pada tiga seksi saja, yaitu seksi I (Berbicara); seksi II (Merespons Kaidah); dan seksi III (Membaca). Untuk seksi IV (Menulis) dan seksi V (Berbicara) tidak dilakukan pada pengujian UKBI di Kabupaten Lampung Utara ini. Hal ini dilakukan karena tes UKBI yang dilakukan pada guru dan siswa ini menggunakan Baterai Tara yang hanya dapat dilakukan pada tiga seksi saja. Seksi ke-4 (Menulis) dan ke-5 (Berbicara) hanya dapat dilakukan oleh Tim UKBI Badan Bahasa dengan menggunakan Baterai Standar.

\section{KERANGKA TEORI}

\subsection{Ikhwal UKBI}

UKBI bertujuan memberikan penilaian standar kemampuan seseorang (pengguna bahasa Indonesia) dalam berbahasa Indonesia tanpa mempertimbangkan kapan, di mana, dan bagaimana kemampuan itu diperoleh. Sehubungan dengan tujuan itu, sering ditanyakan apakah UKBI hanya dapat mengukur kemampuan penutur asli bahasa Indonesia. Pertanyaan selanjutnya adalah apakah kemampuan seseorang yang telah mempelajari bahasa itu sebagai bahasa kedua atau bahasa asing dapat terukur dengan UKBI. Tes ini dirancang tanpa melihat secara langsung situasi apa atau kondisi apa yang telah memengaruhi peserta UKBI dalam pembelajaran bahasa Indonesia. Akan tetapi, sarana pengujian itu dirancang dengan melihat situasi penggunaan bahasa Indonesia yang mungkin akan dihadapi peserta setelah menempuh bicara dan ujian itu. Dalam kaitan itu, sering dikatakan bahwa ada dua situasi pembelajaran bahasa yang berbeda secara ekstrem. Pertama adalah situasi pembelajaran bahasa pertama yang biasanya dilakukan oleh penutur asli. Kedua adalah situasi pembelajaran bahasa kedua yang sering disejajarkan dengan situasi pembelajaran bahasa asing (Pusat Bahasa, 2007). 
Achril Zalmansyah: Uji Kemahiran Berbahasa Indonesia (UKBI) bagi Guru dan ...

Dengan anggapan bahwa setiap penggunaan bahasa terjadi pembelajaran bahasa, secara umum, dapat dikatakan bahwa pengguna bahasa pertama memperoleh kesempatan yang lebih banyak untuk melakukan pembelajaran daripada pengguna bahasa kedua/bahasa asing. Karena itulah, pengguna bahasa pertama sering dijadikan tolok penggunaan bahasa yang ideal (McNamara, 1999). Bahkan, dikatakan bahwa kemahiran tertinggi hanya akan dicapai oleh pengguna bahasa pertama atau penutur asli. Namun, dalam hal kemampuan berbahasa Indonesia, situasi pembelajaran bahasa pertama, kedua, dan bahasa asing menjadi kabur. Hal itu berarti bahwa kemampuan tertinggi tidak hanya dimiliki oleh pengguna bahasa Indonesia sebagai bahasa pertama. Pengguna bahasa Indonesia sebagai bahasa kedua atau asing yang telah mempelajari bahasa itu sebaikbaiknya mungkin sekali akan memiliki kemampuan yang lebih baik daripada pengguna bahasa Indonesia yang lain (Mardiyanto, 2007).

UKBI dikembangkan berdasarkan prinsip penyusunan tes terkini dan telah diujikan kepada berbagai lapisan masyarakat dari berbagai jenjang pendidikan, termasuk sejumlah penutur asing. Hasil UKBI menunjukkan kecocokan dengan kenyataan kemampuan berbahasa Indonesia seseorang. Saat ini, beberapa institusi, baik negeri maupun swasta, telah menjadikan UKBI sebagai alat uji dalam agenda tetap mereka, baik dalam perekrutan pegawai atau karyawan atau untuk keperluan tertentu (Pusat Bahasa, 2007).

Secara umum, materi UKBI adalah penggunaan bahasa Indonesia dalam berbagai situasi dan laras, seperti sejarah, kebudayaan, hukum, teknologi, dan ekonomi. Materi tersebut berasal dari berbagai sumber, baik wacana komunikasi lisan sehari-hari di masyarakat maupun wacana tulis di berbagai media massa, buku acuan, dan tempat umum. Dengan materi itu, UKBI menguji kemampuan seseorang dalam berkomunikasi, baik lisan maupun tulis di dalam bahasa Indonesia. Kemampuan itu dapat diukur dari empat keterampilan, yaitu mendengarkan, membaca, menulis, dan berbicara, serta pengetahuan tentang kaidah bahasa Indonesia (Pusat Bahasa, 2007).

\section{Seksi I (Mendengarkan)}

Seksi ini bertujuan mengukur kemampuan memahami informasi yang diungkapkan secara lisan. Wacana lisan tersebut berbentuk dialog dan monolog yang membahas berbagai topik dalam situasi dan kondisi yang beragam. Seksi ini terdiri atas empat buah dialog dan empat buah monolog. Keseluruhan butir soal berjumlah 40 butir soal pilihan ganda dengan alokasi waktu 25 menit. Setiap dialog atau monolog disertai lima butir soal pilihan ganda yang harus dijawab sekaligus ketika dialog dan monolog tersebut diperdengarkan.

Contoh soal:

1. Dialog tersebut berlangsung di
(A) sebuah ATM
(C) sebuah bank
(B) jalan raya
(D) sebuah kantor

2. Nama Si Laki-laki adalah__ Burhan.
(A) Amat
(C) Muhamad
(B) Ahmad
(D) Achmad

\section{Seksi II (Merespons Kaidah)}

Seksi ini bertujuan mengukur kepekaan peserta uji dalam merespons penggunaan kaidah bahasa Indonesia ragam formal. Kaidah tersebut meliputi ejaan, bentuk dan pilihan kata, serta kalimat. Soal dalam seksi ini terdiri atas satu atau dua kalimat yang memiliki dua bagian yang bergaris bawah dan bercetak tebal. Satu dari dua bagian itu berisi kesalahan dalam penerapan kaidah bahasa Indonesia. Peserta uji harus menentukan satu bagian yang berisi kesalahan dan menentukan satu dari dua pilihan jawaban di bawahnya sebagai jawaban yang benar. Keseluruhan soal yang ada dalam seksi ini berjumlah 25 butir soal pilihan ganda dengan alokasi waktu 20 menit.

Contoh soal:

1. Program pendidikan dan latihan ini sangat berguna.
(A) pelatih
(C) digunakan
(B) pelatihan
(D) dipergunakan

2. X: Dia memang pantas mendapatkan pukulan dan tamparan dari massa.

(A) pukulan dan tamparan oleh

(B) pemukulan dan tamparan dari

Y: Ya. Itulah akibatnya karena mencuri. 
Achril Zalmansyah: Uji Kemahiran Berbahasa Indonesia (UKBI) bagi Guru dan ...

(C) Itulah akibatnya kalau mencuri

(D) Itu akibatnya dari pencurian

Jawaban untuk soal no 1 dan 2 di atas adalah B dan C.

\section{Seksi III (Membaca)}

Seksi ini bertujuan mengukur kemampuan peserta uji dalam memahami informasi yang disampaikan dalam bentuk wacana tulis atau bacaan. Bacaan tersebut disajikan dalam berbagai laras bahasa bidang ilmu. Dalam seksi ini terdapat lima bacaan yang masing-masing diiringi delapan butir soal pilihan ganda. Dalam seksi ini terdapat 40 butir soal pilihan ganda dengan alokasi waktu 45 menit.

Contoh wacana akademik:

Kemiri telah lama dikenal masyarakat sebagai tanaman rempah yang dimanfaatkan untuk bumbu dapur. Kemiri mengandung zat kimia, seperti gliserin,dan asam linoleat serta protein dan vitamin B1. Oleh karena itu, kemiri juga dikenal berkhasiat sebagai penguat dan penyubur rambut. Yang belum dikenal secara luas tentang kemiri adalah bahwa kemiri dapat mengatasi beberapa penyakit. Penyakit yang dapat diatasi dengan kemiri, antara lain demam, diare, disentri, sariawan, sakit gigi, sembelit, dan bisul. Dengan demikian, kemiri juga bermanfaat sebagai obat. Bagian kemiri yang dapat dimanfaatkan adalah biji, kulit batang, dan daunnya.

dst.

Soal:

1. __ kemiri berkhasiat untuk meredakan sakit gigi.
(A) getah batang
(C) kulit batang
(B) getah daun
(D) kulit daun

2. Hingga sekarang kemiri kurang dikenal luas luas sebagai
(A) penyubur rambut
(B) penguat rambut
(C) pereda sariawan
(D) pelengkap bumbu masak

Jawaban untuk soal no 1 dan 2 di atas adalah C dan C.

Dalam UKBI pencapaian hasil tes peserta uji diklasifikasikan ke dalam tujuh peringkat dan ditafsirkan ke dalam tujuh predikat. Ketujuh peringkat dan predikat tersebut ditentukan berdasarkan rentang skor yang ditetapkan dalam UKBI.
Pemeringkatan hasil UKBI ditunjukkan dalam tabel berikut ini.

\begin{tabular}{|c|c|c|}
\hline Peringkat & Predikat & Skor \\
\hline I & Istimewa & $816-900$ \\
\hline II & Sangat Unggul & $717-815$ \\
\hline III & Unggul & $593-716$ \\
\hline IV & Madya & $466-592$ \\
\hline V & Semenjana & $346-465$ \\
\hline VI & Marginal & $247-345$ \\
\hline VII & Terbatas & $162-246$ \\
\hline
\end{tabular}

(Tim UKBI Badan Bahasa)

Peringkat I (Istimewa): Predikat ini menunjukkan bahwa peserta uji memiliki kemahiran yang sempurna dalam berkomunikasi dengan menggunakan bahasa Indonesia, baik lisan maupun tulis. Bahkan, dalam berkomunikasi untuk keperluan keilmuan yang kompleks pun, yang bersangkutan tidak mengalami kendala.

Peringkat II (Sangat Unggul): Predikat ini menunjukkan bahwa peserta uji memiliki kemahiran yang sangat tinggi dalam berkomunikasi dengan menggunakan bahasa Indonesia, baik lisan maupun tulis. Dalam berkomunikasi untuk keperluan keilmuan yang kompleks, yang bersangkutan masih mengalami kendala, tetapi tidak untuk keperluan yang lain.

Peringkat III (Unggul): Predikat ini menunjukkan bahwa peserta uji memiliki kemahiran yang tinggi dalam berkomunikasi dengan menggunakan bahasa Indonesia, baik lisan maupun tulis. Dalam berkomunikasi untuk keperluan keilmuan dan keprofesian yang kompleks, yang bersangkutan masih mengalami kendala.

Peringkat IV (Madya): Predikat ini menunjukkan bahwa peserta uji memiliki kemahiran yang memadai dalam berkomunikasi dengan menggunakan bahasa Indonesia, baik lisan maupun tulis. Dalam berkomunikasi untuk keperluan keprofesian yang kompleks, yang bersangkutan masih mengalami kendala. Kendala tersebut semakin besar jika untuk keperluan keilmuan.

Peringkat V (Semenjana): Predikat ini menunjukkan bahwa peserta uji memiliki kemahiran yang memadai dalam berkomunikasi dengan menggunakan bahasa Indonesia, baik lisan maupun tulis. Dalam berkomunikasi untuk keperluan 
keilmuan, yang bersangkutan sangat terkendala. Untuk keperluan keprofesian dan kemasyarakatan yang kompleks, yang bersangkutan masih mengalami kendala, tetapi tidak terkendala untuk keprofesian dan kemasyarakatan yang tidak kompleks.

Peringkat VI (Marginal): Predikat ini menunjukkan bahwa peserta uji memiliki kemahiran yang tidak memadai dalam berkomunikasi dengan menggunakan bahasa Indonesia, baik lisan maupun tulis. Dalam berkomunikasi untuk keperluan kemasyarakatan yang tidak kompleks, termasuk keperluan kesintasan, yang bersangkutan tidak mengalami kendala. Akan tetapi, untuk keperluan kemasyarakatan yang kompleks, yang bersangkutan masih mengalami kendala. Hal ini berarti yang bersangkutan belum siap berkomunikasi untuk keperluan keprofesian, apalagi untuk keperluan keilmuan.

Peringkat VII (Terbatas): Predikat ini menunjukkan bahwa peserta uji memiliki kemahiran yang sangat tidak memadai dalam berkomunikasi dengan menggunakan bahasa Indonesia, baik lisan maupun tulis. Dengan kemahiran ini, yang bersangkutan hanya siap berkomunikasi untuk keperluan kesintasan. Pada saat yang sama, predikat ini menggambarkan potensi yang bersangkutan dalam berkomunikasi masih sangat besar kemungkinannya untuk ditingkatkan.

\subsection{Guru dan Siswa Sekolah Menengah Pertama sebagai Peserta UKBI}

Sebagai ujung tombak pendidikan dasar dan menengah di Indonesia, guru memegang peranan yang sangat penting bagi keberhasilan pendidikan di negeri ini. Guru yang berhasil adalah guru yang dapat mengantarkan siswa atau anak didik mereka lulus dan berhasil di dalam pendidikannya. Bukanlah suatu hal yang mustahil jika ada guru yang mengajar di desa terpencil yang berhasil mencetak siswa yang berprestasi tingkat provinsi hingga tingkat nasional.

Mengapa UKBI perlu diberikan bagi guru dan siswa? Perlu menjadi pertimbangan bahwa bahasa Indonesia sebagai bahasa resmi nasional yang digunakan dalam pendidikan formal perlu mendapat perhatian khusus, di samping fungsi bahasa Indonesia sebagai bahasa permersatu bangsa. Oleh karena itu, kemampuan guru bidang studi bahasa Indonesia dalam menguasai bahasa Indonesia sudah menjadi hal yang wajib dan dapat menjadi cermin keberhasilannya dalam mendidik siswanya. Bagaimanakah siswa dapat berhasil memperoleh nilai sempurna (100) dalam Ujian Nasional (UN) jika para pengajarnya sendiri memiliki kemampuan yang terbatas dalam penguasaan bahasa Indonesianya? Oleh karena itu, Uji Kemahiran Berbahasa Indonesia (UKBI) ini sangat perlu diberikan bagi guru untuk melihat sejauh mana kemampuan berbahasa para guru ini dan hal-hal apa saja yang diperlukan untuk meningkatkan kemampuan berbahasa Indonesia mereka.

\section{HASIL DAN PEMBAHASAN}

\subsection{Hasil Uji Kemahiran Berbahasa Indonesia bagi Guru Bidang Studi Bahasa Indonesia Sekolah Menengah Pertama Se-Kabupaten Lampung Utara}

Data yang diperoleh dari hasil pengujian UKBI bagi guru SMP bidang studi bahasa Indonesia seLampung Utara ini menunjukkan bahwa sebagian besar peserta, yaitu 26 orang guru (dari 50 orang guru) atau 52\% memperoleh predikat Semenjana dengan kisaran nilai 346-465 (lihat Tabel 1). Data yang diperoleh juga menunjukkan bahwa hanya satu orang peserta saja yang memperoleh predikat tertinggi, predikat Unggul, yaitu 612. Sementara, untuk predikat terendah, yakni Terbatas, terdapat satu orang guru saja dengan nilai perolehan terendah 180 . Sebanyak 16 orang guru (32\%) memperoleh predikat Madya.

Tabel 1 - Hasil UKBI Guru

\begin{tabular}{|c|c|}
\hline Terbatas & 1 \\
\hline Semenjana & 26 \\
\hline Madya & 16 \\
\hline Marginal & 6 \\
\hline Unggul & 1 \\
\hline Total & $\mathbf{5 0}$ \\
\hline
\end{tabular}

\subsection{Hasil Uji Kemahiran Berbahasa Indonesia bagi Siswa Sekolah Menengah Pertama Se- Kabupaten Lampung Utara}

Dari lima puluh orang siswa SMP se-Kabupaten Lampung Utara yang mengikuti pengujian UKBI tahun 2013 ini, diperoleh data sebagai berikut (lihat Tabel 2). 
a) Tak seorang pun $(0 \%)$ yang memperoleh predikat Unggul dengan kisaran nilai 593-716.

b) Dua puluh tujuh siswa (54\%) memperoleh predikat Madya dengan kisaran nilai 466-592.

c) Sembilan belas orang siswa (38\%) memperoleh predikat Semenjana dengan kisaran nilai 346465.

d) Empat orang siswa (8\%) memperoleh predikat Marginal dengan kisaran nilai 247-345.

e) Tak seorang siswa pun (0\%) yang memperoleh predikat Terbatas dengan kisaran nilai 162-246.

Tabel 2 - Hasil UKBI Siswa

\begin{tabular}{|c|c|}
\hline Terbatas & 0 \\
\hline Semenjana & 19 \\
\hline Madya & 27 \\
\hline Marginal & 4 \\
\hline Unggul & 0 \\
\hline Total & $\mathbf{5 0}$ \\
\hline
\end{tabular}

\subsection{Hasil UKBI bagi Guru dan Siswa Sekolah}

\section{Menengah Pertama Se-Kabupaten Lampung}

\section{Utara Tahun 2013}

Kegiatan Uji Kemahiran Berbahasa Indonesia bagi guru dan siswa sekolah menengah pertama seKabupaten Lampung Utara yang dilaksanakan di SMP Bayangkari, Kotabumi, Lampung Utara pada tanggal 2-4 September 2013 ini diikuti oleh seratus peserta yang terdiri dari lima puluh orang guru bidang studi bahasa Indonesia (50\%) dan lima puluh orang siswa SMP (50\%).

Secara keseluruhan, data yang diperoleh dari hasil pengujian UKBI guru dan siswa SMP se-Kabupaten Lampung Utara ini adalah sebagai berikut.

a) Satu peserta (1\%) memperoleh predikat Unggul dengan kisaran nilai 593-716.

b) Empat puluh tiga peserta (43\%) memperoleh predikat Madya,dengan kisaran nilai 466-592.

c) Empat puluh lima peserta (45\%) memperoleh predikat Semenjana dengan kisaran nilai 346465.

d) Sepuluh peserta $(10 \%)$ memperoleh predikat Marginal dengan kisaran nilai 247-345.

e) Sisanya satu peserta (1\%) memperoleh predikat Terbatas dengan kisaran nilai 162-246.

f) Tak seorang peserta pun yang memperoleh predikat Sangat Unggul dan Istimewa.

Tabel 3 - Hasil UKBI Guru dan Siswa

\begin{tabular}{|c|c|}
\hline Terbatas & 1 \\
\hline Semenjana & 45 \\
\hline Madya & 43 \\
\hline Marginal & 10 \\
\hline Unggul & 1 \\
\hline Total & $\mathbf{1 0 0}$ \\
\hline
\end{tabular}

Berikut grafik distribusi nilai UKBI guru dan siswa SMP se-Kabupaten Lampung Utara tahun 2013.

Distribusi Hasil UKBI (\%)

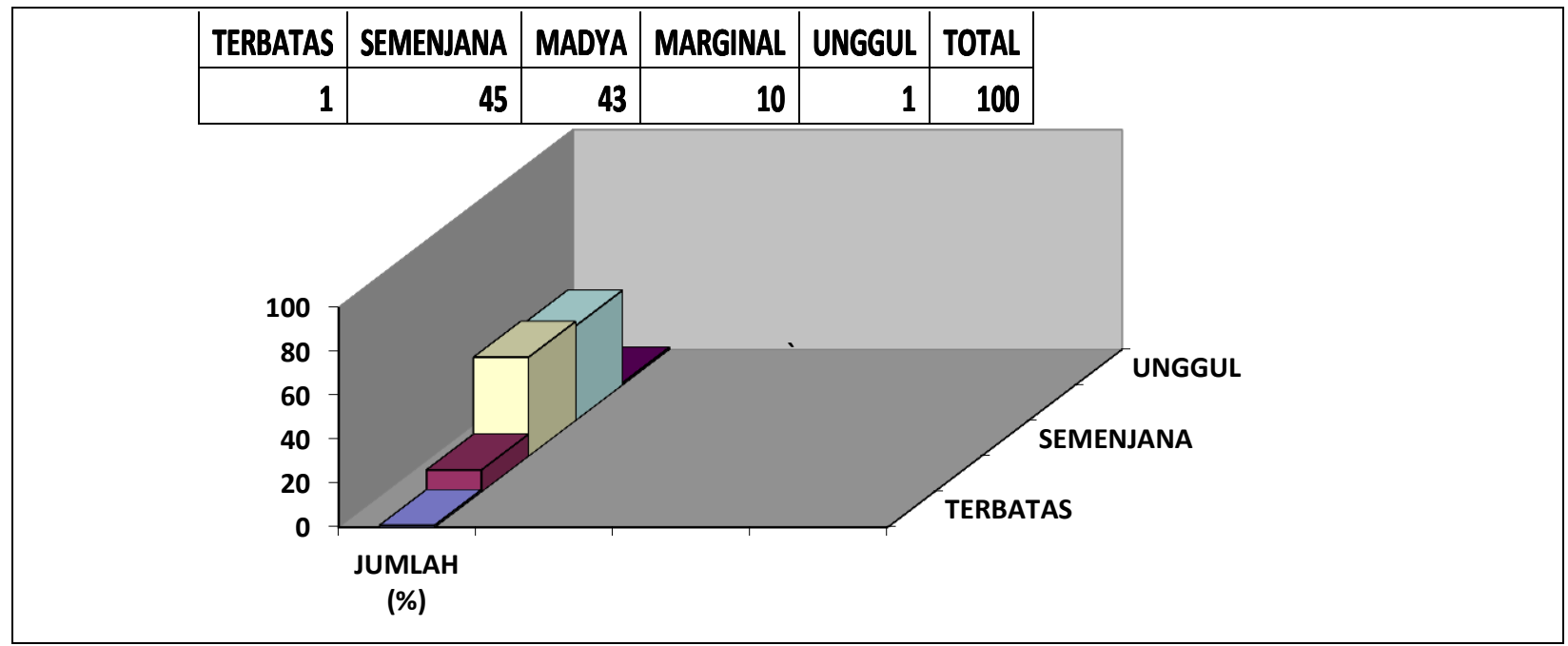

Berdasarkan data di atas, dapat dikatakan bahwa kemampuan peserta UKBI sebagian besar berada pada peringkat Semenjana (45\%) dan diikuti oleh predikat
Madya (43\%). Hal ini menunjukkan bahwa hampir terdapat keberimbangan antara perolehan peringkat Semenjana dengan peringkat Madya. Dari keseluruhan 
peserta, ternyata tidak ada seorang pun yang pernah mengikuti tes UKBI, baik di sekolahnya maupun di Kantor Bahasa Provinsi Lampung sebagai pelaksana atau instansi yang berwenang menyelenggarakan tes ini.

Dengan demikian, dapat dikatakan bahwa tingkat pengenalan dan pemahaman para guru bidang studi bahasa Indonesia dan siswa sekolah menengah pertama yang ada di Kabupaten Lampung Utara terhadap Uji Kemahiran Berbahasa Indonesia (UKBI) pada tahun 2013 sudah cukup baik, mengingat tes ini merupakan tes UKBI yang pertama kali mereka lakukan. Keberhasilan seorang guru bidang studi bahasa Indonesia dalam mengikuti pelatihan dan pengujian UKBI ini merupakan cermin keberhasilan mereka dalam mata pelajaran bahasa Indonesia di sekolahnya. Peningkatan mutu dan hasil yang lebih baik dapat dilakukan dengan berbagai cara, salah satunya dengan mengikutsertakan para guru dan siswa ini di dalam kegiatan yang bersifat peningkatan mutu kebahasaan, seperti seminar kebahasaan dan penyuluhan bahasa Indonesia.

Akhirnya, penulis beranggapan bahwa UKBI ini sangat perlu diterapkan di kalangan guru dan siswa di dalam upaya meningkatkan mutu dan pengetahuan mereka akan mata pelajaran bahasa Indonesia dan memupuk kebanggaan mereka terhadap bahasa Indonesia.

\section{PENUTUP}

\subsection{Simpulan}

Uji Kemahiran Berbahasa Indonesia (UKBI) yang dilakukan terhadap para guru dan siswa sekolah menengah pertama yang ada di Kabupaten Lampung Utara ini dapat dikatakan sangat efektif dan bermanfaat untuk mengetahui bagaimana pengetahuan dan penguasaan mereka terhadap bahasa Indonesia. Semakin baik hasil yang mereka peroleh pada tes UKBI ini, akan semakin baik pula penguasaan dan kemampuan mereka dalam berbahasa Indonesia.

Berdasarkan data di atas, dapat disimpulkan bahwa hasil UKBI para guru dan siswa sekolah menengah pertama se-Kabupaten Lampung Utara pada tahun 2013 ini dapat dikatakan cukup baik, artinya sebagain besar peserta berada pada peringkat Madya dan Semenjana, dengan perolehan angka rata-rata antara 300 -an sampai dengan angka 400-an yang. Hal ini disebabkan peserta masih mengalami kendala dalam berkomunikasi untuk keperluan keprofesian yang kompleks dan masih mengalami kendala yang besar jika berkomunikasi untuk keperluan keilmuan.

Oleh karena itu, Uji Kemahiran Berbahasa Indonesia (UKBI) sangat perlu diberikan pada semua tingkatan atau jenjang pendidikan, baik sekolah dasar, sekolah menengah pertama, maupun sekolah menengah atas.

\subsection{Saran}

Pengenalan dan pemahaman terhadap Uji Kemahiran Berbahasa Indonesia (UKBI) di kalangan guru dan siswa perlu ditingkatkan sebagaimana baiknya pengenalan dan pemahaman mereka terhadap tes sejenis pada mata pelajaran lain. Peningkatan mutu para guru, khususnya bidang studi bahasa Indonesia sangat perlu ditingkatkan melalui kegiatan kebahasaan seperti penyuluhan bahasa Indonesia, seminar kebahasaan, dan sebagainya. Sosialisasi dan pelatihan tentang UKBI juga perlu dilakukan untuk memasyarakatkan tes ini baik di kalangan, pelajar dan mahasiswa, maupun para guru tingkat sekolah dasar hingga guru sekolah menengah atas.

\section{DAFTAR PUSTAKA}

Bachman, Lyle F. 1990. Fundamental Considerations in Language Testing. Oxford: Oxford University Press.

Chaer, Abdul dan Leonie Agustina. 2010. Sosiolinguistik-Perkenalan Awal. Edisi Revisi. Jakarta: Rineke Cipta.

Kompas.com. 2009. ”Tulisan Mengenai UKBI,” edisi Rabu, dalam www.kompas.com, 12 Agustus 2009.

Laman UKBI, diakses Jumat, 20 Maret 2009.

Maryanto. 2007. Tes UKBI dan Pengajaran BIPA. Jakarta: Pusat Bahasa.

McNamara, T.F. 1996. Measuring Second Language Performance. London dan New York: Longman. 
Achril Zalmansyah: Uji Kemahiran Berbahasa Indonesia (UKBI) bagi Guru dan ...

Pusat Bahasa. 2007. Buklet UKBI, Edisi Kedua. Jakarta: Pusat Bahasa.

Pusat Bahasa. 2008. Kamus Besar Bahasa Indonesia Pusat Bahasa, Edisi Keempat. Jakarta: Gramedia.

Pusat Bahasa. Bedah Soal UKBI, Seri Pelatihan, Edisi Ketiga. Jakarta: Koperasi Primer Pusat Bahasa.

\section{CATATAN BELAKANG}

1) Penilaian standar ialah penilaian yang menggunakan instrumen dan administrasi pengujian yang telah dibakukan serta menggunakan hasil penelitian empiris tentang reliabilitas dan validitas yang berkaitan dengan instrumen dan administrasi pengujian itu (Bachman, 1992: 74). 